\title{
AT-TARBAWI
}

At-Tarbawi: Jurnal Pendidikan, Sosial dan Kebudayaan

Volume 6 Nomor 1 Tahun 2019

doi: 10.32505/tarbawi.v6i1.1064

\section{Pandangan Positif Matematika terhadap Internalisasi Nilai "Performance Character" dalam Pembelajaran Matematika Sekolah Dasar}

\author{
Sabaruddin'; Rosnidar Mansor ${ }^{2}$ \\ 1IAIN Langsa \\ 2Universiti Pendidikan Sultan Idris (UPSI), Perak Malaysia \\ sabaruddin@iainlangsa.ac.id; rosnidar@fppm.upsi.edu.my
}

\begin{abstract}
This article has a purpose to discuss character building for students at the elementary level by developing a positive attitude and positive opinion towards mathematics. The Indonesian government today continuously has tried to improve the quality of education by revising curriculum to all levels of education starting from elementary school to senior high school. The new implemented curriculum focus on the implementation of character which is integrated with all school subjects including mathematics. Character building at the elementary level becomes the main concern for all people because the main focus at the elementary level is more on building a good attitude rather than on knowledge and skill. This paper describes how to develop performance character and mathematics positively which includes confidence, positive view towards mathematics, improve students' patience, improve student's competence, praise for the student's effort, develop student's cleverness and gives motivation. By developing performance character and mathematics positivity could create an effective mathematics class, improve students' behaviour, avoid students constrain in learning mathematics and enhance students' interest in learning mathematics.
\end{abstract}

keywords: elementary school, Mathematics Learning, Performance Character

\begin{abstract}
Abstrak
Penulisan ini bertujuan mendiskusikan tentang pembentukan karakter murid sekolah dasar dengan membangun kelakuan dan pandangan positif terhadap matematika. Pemerintah Indonesia saat ini secara terus menerus meningkatkan kualitas pendidikan dengan merevisi kurikulum pada semua jenjang pendidikan mulai dari sekolah dasar hingga ke sekolah menengah. Kurikulum yang baru diterapkan sekarang berfokus pada penerapan karakter secara integratif dalam semua pelajaran termasuk pelajaran matematikaa. Pengembangan karakter pada jenjang Sekolah Dasar menjadi perhatian semua kalangan dikaranakan komposisi pendidikan pada jenjang sekolah dasar lebih besar kepada pembentukan sikap berbanding dengan pengetahuan dan kompetensi. Artikel ini mendiskusikan tentang bagaimana membangun Performance Character \& Math Positivity yang meliputi keyakinan diri, menghilangkan pandangan negatif terhadap matematikaa dan memberikan motivasi kepada murid dalam meningkatn kemampuan matematikaa. Dengan membangun Performance Character \& Math Positivity dapat menciptakan kelas matematikaa yang efektif, meningkatkan kelakuan murid dan manjauhkan murid dari perasaan terkekang dalam belajar matematika serta dapat meningkatkan minat murid dalam belajar matematika.
\end{abstract}

Kata Kunci: Performance Character, Pembelajaran Matematika, dan Sekolah Dasar 


\section{A. Pendahuluan}

Pada titik ini pengembangan pemahaman dan karakter merupakan masalah penting dalam sistem pendidikan di Indonesia. Upaya untuk menghidupkan kembali pendidikan karakter ini adalah mandat yang diuraikan dalam UU No. 20 tahun 2003 tentang Sistem Pendidikan Nasional, dalam Pasal 3 disebutkan bahwa pendidikan nasional berfungsi untuk mengembangkan dan membentuk nilai-nilai dan peradaban suatu bangsa yang bermartabat untuk memperkaya kehidupan bangsa. Pembentukan karakter adalah salah satu fokus pendidikan nasional. Pasal 1 UU N0. 202003 menyatakan bahwa salah satu fokus pendidikan nasional adalah pada pengembangan potensi siswa untuk keunggulan intelektual, moral dan moral. Kepercayaan Undang-Undang Sistem Pendidikan Nasional tahun 2003 berarti bahwa pendidikan tidak hanya akan membentuk orang Indonesia yang cerdas secara intelektual, tetapi juga karakter atau karakter, untuk melahirkan generasi orang yang berkembang dengan nilai-nilai tinggi ras dan agama.

Pendidikan karakter yang dikombinasikan dengan pembelajaran berbagai bidang studi dapat memberikan siswa pengalaman yang bermakna ketika mereka memahami, mengalami, dan menciptakan melalui proses pembelajaran (Darmiyati Zuchdi, 2010). Pada tahun 2010, Kementerian Pendidikan dan Kebudayaan di Indonesia membentuk program pendidikan karakter nasional, yang telah dilaksanakan di semua sekolah di Indonesia. Pada 2013, kementerian memperkenalkan kurikulum baru dengan penekanan pada keterampilan dan karakter. Sistem pembelajaran dalam kurikulum ini semuanya terintegrasi dengan pendidikan karakter dan sistem pembelajaran tematik. Pada tingkat dasar, implementasi sistem pembelajaran tematik sepenuhnya dilaksanakan, sedangkan pada tingkat sekolah menengah bersifat tematik dan subyektif (Darmiati Zuchdi, 2010).

Karakter adalah persamaan dari dua komponen dasar: kinerja karakter dan moral karakter. Kinerja karakter terdiri dari kualitas yang dicari seperti ketekunan, ketekunan, etos kerja yang kuat, sikap positif, kecerdasan, dan harga diri yang dibutuhkan untuk menciptakan potensi seseorang untuk 
menjadi yang terbaik dalam setiap bidang kegiatan seperti kegiatan ekstrakurikuler akademik, pekerjaan, dan pembelajaran seumur hidup (Lickona \& Davidson, 2005; Nucci \& Narvaeez, 2008). Karakter moral, pada gilirannya, mencakup sifat-sifat yang termasuk tetapi tidak terbatas pada integritas, keadilan, kepedulian, rasa hormat, dan kerja sama yang diperlukan untuk hubungan interpersonal orang lain dan diri kita sendiri dengan rasa hormat dan perhatian serta bertindak dengan integritas dalam kehidupan etis kita (Lickona \& Davidson, 2005, Nucci \& Narvaeez, 2008).

Selama ini pembentukan karakter pelajar adalah hanya melalui pembelajaran pendidikan karakter sahaja, malah mata pelajaran matematika tidak ada kaitannya dengan pembentukan karakter pelajar (Melinda Bier, 2005). Anggapan sangat tidak sesuai dengan kaedah pembelajaran matematika yang terdiri daripada nilai matematika dan nilai pendidikan matematika (Bishop \& Seah, 2002). Oleh itu, untuk membentuk karakter pelajar, tidak perlu melalui satu mata pelajaran sahaja, tetapi boleh juga di diintegrasi ke dalam setiap mata pelajaran, termasuk pada mata pelajaran matematika (Prayitno \& Manullang, 2011; Muslich, 2011). Hal ini selaras dengan kenyataan Ahmad Sudrajat (2010) bahawa pendidikan karakter dapat di integrasikan dalam pembelajaran pada setiap mata pelajaran. Pembelajaran yang berkaitan dengan norma atau nilai-nilai pada setiap mata pelajaran perlu dibangunkan, diterapkan, dikaitkan dengan konteks kehidupan sehari-hari. Oleh itu, pembelajaran nilai-nilai karakter tidak hanya pada taraf kognitif, tetapi menyentuh pada tahapan pemupukan dan pengamalan yang sebenar dalam kehidupan harian pelajar dalam masyarakat.

\section{B. Metode}

Metode penelitian ini menggunakan studi kepustakaan. Studi kepustakaan yang digunakan sebanyak 36 referensi. 


\section{Hasil dan Pembahasan}

Performance character menggambarkan seperangkat kebajikan ketika mereka mendekati tugas atau tujuan yang ingin mereka capai. Karakter tidak hanya melakukan hal yang benar secara etis, karakter adalah tentang melakukan pekerjaan terbaik. Jika itu benar, maka fitur pendidikan tidak hanya tentang membantu anak-anak berinteraksi, karakter juga tentang mengajar mereka untuk bekerja keras, mengembangkan bakat mereka, dan bercita-cita untuk unggul dalam upaya mereka. (Lickona, 2005).

\section{Keyakinan Diri Terhadap Kemampuan}

Langkah penting dalam mempelajari segala sesuatu yang memiliki sikap positif dan kepercayaan diri pada kemampuan seseorang untuk mempelajari sesuatu yang baru. Bandura (1997) menunjukkan bahwa kepercayaan dan kemampuan untuk berhasil dalam tugas mempengaruhi bagaimana seseorang berpikir dan berperilaku. Tidak peduli apa pun tujuan sebenarnya dari kemampuan mereka, keyakinan subjektif siswa tentang kemampuan mereka dapat membimbing mereka dalam pilihan yang mereka buat, upaya dan ketekunan yang mereka buat ketika mereka menghadapi hambatan (Walton Spencer, 2009).

Studi terbaru telah menunjukkan bahwa persepsi kemampuan siswa adalah prediktor yang lebih baik dari prestasi akademik daripada kemampuan mereka yang sebenarnya (Pajares Schunk, 2002) dan siswa berbakat sering gagal mencapai potensi akademik mereka. Namun, sebagian besar siswa, orang tua dan guru kurang percaya pada kemampuan siswa dalam matematika dan ini mungkin memiliki efek yang terlihat. Studi tentang kecemasan matematika di kalangan siswa telah menemukan bahwa sebagian besar pendidikan dasar memiliki tingkat kecemasan matematika tertinggi (Hembree, 1990).

Satu dari lima orang dewasa di Amerika Serikat tidak memiliki keterampilan matematika yang diharapkan dari siswa kelas delapan, menurut informasi dari Pusat Pendidikan Statistik Amerika Serikat. Lebih lanjut, hasil penilaian National Adult Literacy (NAAL) mengungkapkan bahwa hanya $13 \%$ orang dewasa AS yang berada dalam lingkungan 
kemahiran matematika yang memungkinkan mereka untuk menghitung dan membandingkan biaya per ons makanan (Kutner et al., 2006). Dalam sampel acak orang dewasa Amerika, 78\% tidak dapat mengetahui cara menghitung bunga yang dibayarkan pada pinjaman, 71\% tidak dapat menghitung jarak tempuh di jalan, dan 58\% masih tidak bisa menghitung tip 10\% untuk server yang melayani makan siang di restoran.

\section{Memerangi Pandangan Negatif Matematika Pada Pelajar}

Sebagian besar anak-anak dan remaja memiliki perasaan negatif tentang matematika. Belajar mencintai matematika. Strategi mengajar mempengaruhi sikap dan kinerja siswa (Judy Willis, 2010). Guru matematika ikut serta dalam membimbing siswa. Harapan yang rendah untuk sukses adalah pengalaman negatif, kurangnya keterampilan dan persiapan untuk melakukan matematika, kegagalan untuk terlibat dalam matematika melalui pembelajaran individu dan takut melakukan kesalahan (Aronson \& Inzlicht, 2003; Stephanou 2012; Willis, 2010).

Pusat Studi Psikologi dan Perilaku mendukung Willis (2010) efek matematika negatif dan pengalaman kelas yang kurang percaya diri dalam matematika. Efek negatif ini termasuk stres tinggi, motivasi rendah, perasaan tidak mampu dan frustrasi, berkurangnya partisipasi kelas, kebosanan, penurunan toleransi terhadap tantangan, kegagalan bersaing di kelas, masalah perilaku dan menghindari kelas matematika tambahan yang diperlukan untuk sukses tahap selanjutnya (Diener Dweck, Hansen 1994; Stephanou 2004, 2012; Willis, 2010).

Sejumlah standar pembelajaran sosial dan teori-teori penelitian ekspektasi telah menunjukkan bahwa siswa cenderung aktif terlibat dalam kegiatan ketika mereka percaya bahwa mereka dapat berhasil tetapi mereka cenderung menghindari kegiatan sehingga mereka tidak memiliki kepercayaan diri untuk berhasil (Kyriacou \& Goulding, 2004). Bagaimana siswa mengembangkan kepercayaan diri yang dikenal sebagai self-efficacy. Para peneliti telah mengidentifikasi tiga sumber utama self-efficacy keberhasilan atau kegagalan pengalaman representasional atau yang 
dirasakan lainnya sebagai kemiripan diri dan kepercayaan sosial atau pesan yang diterima dari orang lain (Usher \& Pajares, 2008).

Guru, orang tua, dan teman sebaya adalah bagian penting dari pengembangan rasa percaya diri siswa untuk mendorong upaya diri siswa (De Witz, Woolsey, \& Walsh, 2009). Namun, ketika harapan orang tua, guru dan teman sebaya terlalu tinggi pada prestasi siswa, mereka mungkin kurang termotivasi untuk bertahan pada tugas. Oleh karena itu, dapat menggunakan strategi yang mendorong pengalaman sekolah yang positif dan menggunakan ingatan untuk mengaktifkan perasaan kompetensi dan motivasi siswa.

Guru dapat memicu ingatan positif pada awal tahun baru dengan mendorong siswa untuk menulis tentang kegiatan matematika yang menarik mereka dari tahun sebelumnya. Hampir semua siswa dapat menghargai setidaknya satu pengalaman matematika positif, meskipun guru-guru ini dapat membuka dan menggunakan pertanyaan alternatif seperti 'Apa pengalaman Anda yang paling menarik tahun lalu?' atau 'Apa kegiatan matematika terbaik yang dapat Anda ingat dari tahun sebelumnya?'. Menciptakan rasa percaya diri bisa menjadi tugas pertama bagi matematika siswa untuk dipertahankan dan dapat diteruskan ke guru tahun depan.

Judy Willis (2010) menunjukkan minat siswa sebagai individu dengan memberi mereka kesempatan untuk memberi tahu mereka apa yang mereka sukai tentang matematika dan apa yang telah dilakukan guru di masa lalu apakah akan membantu mereka atau tidak. Willis memberi siswa pertanyaan untuk membantu memfokuskan jawaban mereka. Apa yang Anda sukai dari kerja kelompok. Apa yang Anda lakukan ketika Anda mengalami kesulitan? Bagaimana Anda menghafal materi? Apa yang Anda lakukan secara berbeda ketika Anda paling sukses daripada ketika Anda paling tidak berhasil? Apa yang telah dilakukan guru Anda di masa lalu yang telah membantu Anda belajar lebih baik? Bagaimana Anda menggunakan matematika di luar sekolah? Apakah orang tua Anda atau kerabat dekat Anda memiliki pekerjaan atau hobi di mana mereka menggunakan matematika? Willis menggunakan pertanyaan-pertanyaan ini untuk membantunya memilih strategi untuk digunakan atau dihindari dalam membedakan kegiatan belajar bagi siswa. 


\section{Membina Ketekunan}

Membangun ketahanan siswa untuk ketekunan dalam pencapaian tujuan adalah hasil dari program pendidikan karakter yang ditargetkan dengan jelas yang merupakan bagian dari standar pertama praktik matematika. Memahami masalah menjadi solusi pemecahan masalah adalah prinsip tugas akademik (Farrington et al., 2012). Sebagai kecenderungan siswa untuk menyelesaikan tugas sekolah pada waktu yang tepat, dengan kemampuan terbaiknya, terlepas dari kendala, hambatan dan tantangan termasuk kekuatan ketekunan (Duckworth \& Quinn, 2012). Bahkan, studi Farrington, et al. (2012) mengembangkan model logika tentang bagaimana apa yang mereka sebut faktor kognitif bukan satu-satunya faktor yang mempengaruhi kinerja akademik. Model tersebut mencerminkan pemikiran akademik yang mengarah pada kegigihan akademik, yang meningkatkan perilaku akademik yang pada akhirnya menghasilkan kinerja akademik yang lebih baik.

\section{Latihan Kecakapan}

Farrington et al. (2012) menggambarkan model dalam beberapa studi penelitian psikologis. Penelitian ini mencakup pekerjaan dasar pada kepribadian, motivasi, dan teori pembelajaran sosial (Dweck Leggett, 1988; Eccles, Adler, Futterman, Goff, Kaczala, Meece, Midgley, 1983) yang mendukung gagasan bahwa siswa lebih cenderung bertahan melalui masalah sulit dan berhasil secara akademis jika mereka memiliki 'pertumbuhan' sebagai lawan dari pemikiran 'tetap'. Siswa dengan mindset tetap percaya bahwa kemampuan adalah karakteristik tetap atau alami yang mereka miliki sedikit atau tidak ada kontrol.

Sejumlah kecil intervensi telah menunjukkan keberhasilan dalam mengatasi penyebab dan efek negatif dari matematika yang dibahas sebelumnya. Beberapa tahun terakhir telah menunjukkan bahwa tampaknya intervensi psikologis sosial tidak mengajarkan konten akademik tetapi malah menargetkan pikiran, perasaan, dan keyakinan siswa dan bahwa sekolah telah memiliki dampak yang signifikan dan bertahan lama pada prestasi 
pendidikan bahkan selama berbulan-bulan dan bertahun-tahun (Garcia Cohen, 2012; Gehlbach, 2010; Dweck Walton, 2009; Walton Spencer, 2009; Wilson, 2006; Yeager Walton, 2011).

Matematika sekolah menengah di seluruh Amerika Serikat yang menghasilkan dampak terbesar pada hasil pendidikan termasuk mengurangi persentase siswa yang mengulang aljabar dari 24\% menjadi 9\% (Stano, 2012; Yeager Walton, 2011). Beberapa studi eksperimental telah membuat hasil yang signifikan dalam pencapaian matematika SMA setelah implementasi kegiatan yang dirancang untuk memperkenalkan dan memperkuat gagasan bahwa kecerdasan mudah dibentuk, karena otot menjadi lebih kuat dengan pelatihan (Blackwell, Trzesniewski \& Dweck, 2007; Bagus, Aronson \& Inzlicht, 2003).

\section{Upaya Pujian dan Penghargaan untuk Meningkatkan Kemampuan}

Mueller dan Dweck (1998) dalam studi eksperimental menyediakan satu set masalah sederhana untuk siswa kelas lima. Satu kelompok siswa menerima pujian karena kemampuan mereka. Semua siswa kemudian diberikan satu set masalah yang sangat sulit yang mereka semua lakukan dengan baik. Akhirnya, siswa diberi satu set masalah yang sulit. Di set terakhir ini masalah pujian netral siswa dilakukan pada tingkat yang sama seperti mereka di set pertama. Upaya pujian mendorong siswa untuk melakukan lebih baik dari yang semula mereka lakukan dan memotivasi mereka untuk meminta masalah yang lebih menantang di masa depan. Hanya satu kalimat yang mencerminkan prestasi siswa setelah kegagalan, sementara hanya satu kalimat yang mengakui efek positif dari upaya mempromosikan kinerja yang lebih baik setelah kegagalan mereka.

\section{Membangun Potensi Kemampuan}

Sebuah studi di mana siswa sekolah menengah secara acak dibagi menjadi dua kelompok, satu kelompok yang terdiri dari situasi perawatan yang mencakup menghadiri lokakarya yang mencakup delapan sesi untuk mengajarkan keterampilan belajar dan berbagi hasil penelitian ilmiah yang 
menunjukkan bagaimana menjadi lebih pintar ketika seseorang berupaya melakukan tugas-tugas yang menantang (Blackwell et al. 2007). Siswa sekolah menengah dalam kelompok kontrol diberikan delapan sesi di mana mereka hanya belajar keterampilan.

Hasil menunjukkan bahwa siswa belajar dari apa yang kemudian disebut mindset berkembang mendapatkan matematika yang lebih baik sepanjang tahun sementara siswa dalam kelompok kontrol melanjutkan di bawah lintasan kelas matematika yang biasa. Belajar tentang keterampilan saja tidak cukup untuk menghasilkan kinerja belajar yang lebih baik dalam matematika. Siswa membutuhkan motivasi untuk mendapatkan keterampilan. Kekuatan mendorong intervensi lain berdasarkan teori-teori ini telah menghasilkan manfaat akademis yang serupa di banyak populasi (Aronson, Fried \& Good, 2002; Good et al, 2003).

\section{Mengekalkan Motivasi dan Menghapuskan Ganjaran}

Sebagian besar guru terkadang harus memberikan penghargaan sebagai strategi motivasi. Siswa mendapat permen untuk jawaban yang benar dan guru memberi mereka hadiah untuk ditukar dengan pekerjaan rumah, membantu teman sekelas mereka menguasai konsep yang sulit, atau hanya mengambil sampah di kebun. Motivasi perlu perhatian serius untuk membentuk karakter siswa, dan karena hadiah atau hukuman atau hadiah dapat membentuk pemikiran siswa, guru perlu mengurangi hadiah yang mungkin membuat siswa takut melakukannya. Hali diperkuat dari sebuah penelitian yang memberikan hadiah kepada anak-anak pra-sekolah dapat melakukan pekerjaan melukis dengan baik dibandingkan dengan kegiatan yang tidak memenangkan penghargaan. Motivasi penghargaan harus didorong oleh guru untuk memotivasi siswa yang baik (Lepper Greene, 1978). 


\section{Kesimpulan}

Kekuatan karakter dilengkapi dengan kegiatan yang mengembangkan karakter intelektual, sipil dan moral karakter. Sangat penting untuk menyadari bahwa dimensi karakter tidak berbeda tetapi sangat terintegrasi. Dalam diskusi berikut kami meninjau penelitian yang menunjukkan bahwa nilai karakter berfokus pada strategi pencapaian matematika. Strategi penelitian didukung untuk membangun kepercayaan akademis dan ketekunan serta kekuatan karakter lainnya termasuk pertemuan kelas, nilainilai janji, keterlibatan orang tua, dan memberikan contoh penggunaannya dalam pengajaran dan pembelajaran matematika. Dari pembahasan di atas dapat disimpulkan bahwa matematika adalah bagian penting dari pendidikan. Matematika tidak hanya kecerdasan intelektual, ia juga dapat membentuk karakter karakter dengan meningkatkan kepercayaan diri, perilaku, membangun potensi untuk penguasaan, dan melatih keterampilan. Oleh karena itu, dalam proses belajar mengajar matematika perlu untuk mengembangkan karakter dan sikap positif dalam pengajaran matematika terutama di tingkat SD.

\section{DAFTAR PUSTAKA}

Aronson, J., Fried, C. B., \& Good, C. (2002). Reducing the effects of stereotype threat on African American college students by shaping theories of intelligence. Journal of Experimental Social Psychology, 38(2), 113125.

Bandura, A. (1993). Perceived self-efficacy in cognitive development and functioning. Educational Psychologist, 28(2), 117-148.

Bandura, A. (1997). Self-efficacy: the exercise of control. New York, NY: Worth Publishers

Bier, Melinda C; Berkowitz, Marvin W, (2005), what works in character education, Leadership for Student Activities, Reston, Vol. 34, Num. 2, Oktober 2005, p. 7-13.

Bishop, A. J., \& Seah, W. T. (2002). Values, mathematics and society: Making the connections. diambil: 1 Ogos, 2010 
Blackwell, L. S., Trzesniewski, K. H., \& Dweck, C. S. (2007). Implicit theories of intelligence predict achievement across an adolescent transition: $A$ longitudinal study and an intervention. Child Development, 78(1), 246-263.

Cohen, G. L., Garcia, J., Purdie-vaughns, V., Apfel, N., \& Brzustoski, P. (2009). Recursive processes in self-affirmation: intervening to close the minority achievement gap. Science, 324 (April), 400-403.

DeWitz, S. J., Woolsey, M. L., \& Walsh, W. B. (2009). College student retention: An exploration of the relationship between self-efficacy beliefs and purpose in life among college students. Journal of College Student Development, 50(1), 19-34.

Duckworth, A. L., Quinn, P. D., \& Tsukayama, E. (2012). What No Child Left leaves behind The roles of IQ and self-control in predicting standardized achievement test scores and report card grades. Journal of Educational Psychology, 104(2), 439-451.

Dweck, C, Walton, G., \& Cohen, G. (2011). Academic tenacity: Mindset and skills that promote long-term learning. Gates Foundation. Seattle, (pp. 1-76).

Dweck, C.S. (2000). Self-theories: Their role in motivation, personality and development. Taylor \& Francis: Philadelphia, PA.

Eccles, Parsons, J., Adler, T. F., Futterman, R., Goff, S. B., Kaczala, C. M., Meece, J. L., \& Midgley, C. (1983). Expectancies, values, and academic behaviours. In J. T. Spence (Ed.), Achievement and

Farrington, C. A., Roderick, M., Allensworth, E., Nagaoka, J., Keyes, T. S., Johnson, D. W., \& Beechum, N. O. (2012). Teaching adolescents to become learners the role of noncognitive factors in shaping school performance: A critical literature review. Chicago, IL: the University of Chicago Consortium on Chicago School Research.

Gehlbach, H. (2010). The social side of school: Why teachers need social psychology. Educational Psychology Review, 22, 349-362.

Good, C., Aronson, J., \& Inzlicht, M. (2003). Improving adolescents' standardized test performance: An intervention to reduce the effects of stereotype threat. Journal of Applied Developmental Psychology, $24(6), 645-662$.

Hembree, R. (1990). The nature, effects, and relief of mathematics anxiety. Journal for Research in Mathematics Education, 21(1), 33-46. 
Kutner, M., Greenberg, E., Jin, Y., Boyle, B., Hsu, Y., and Paulsen, C. (2006). Literacy in Everyday Life: Results From the 2003 National Assessment of Adult Literacy (NCES 2006-477). National Center for Education Statistics, Institute of Education Sciences, U.S. Department of Education. Washington, DC

Lepper, M. R., \& Greene, D. E. (1978). The hidden costs of reward: New perspectives on the psychology of human motivation. Mahwah, NJ: Erlbaum.

Lickona, T., \& Davidson, M. (2005). Smart \& Good High Schools: Integrating Excellence and Ethics for Success in School, Work, and Beyond. Cortland, New York.

Lickona, Thomas \& Matthew Davidson. (2004). Smart \& Good High School: Integrating Excellence and Ethics for Success in Schools, Work, and Beyond. Cortland

Lickona. Thomas. (2013). Pendidikan Karakter-Panduan Lengkap Mendidik Siswa Menjadi Pintar dan Baik (Terjemahan dari Educating for Character, 2008 oleh Lita S), Bandung: Nusa Mesia.

Mueller, C. M., \& Dweck, C. S. (1998). Praise for intelligence can undermine children's motivation and performance. Journal of Personality and Social Psychology, 75(1), 33-52.

Muslich, Mansur. (2011). Pendidikan Karakter. Jakarta: Bumi Aksara

Narvaez, D., \& Lapsley, D. (2008). Teaching moral character: Two alternatives for teacher education. The Teacher Educator, 1-10.

Pajares, F., \& Schunk, D. H. (2002). Self and self-belief in psychology and education: A historical perspective. In J. Aronson (Ed.) Improving academic achievement: Impact of psychological factors on education, (pp. 3-21). San Diego, CA: Academic Press.

Prayitno \& Belferik, M. (2011). Pendidikan Karakter dalam Pembangunan Bangsa. Medan: Penerbit Pascasarjana Universitas Negeri Medan.

Stephanou, G. (2012). Students' school performance in language and mathematics: Effects of hope on attributions, emotions and performance expectations. International Journal of Psychological Studies 4(2), 93-120.

Stone, D., Deci, E., \& Ryan, R. (2008). Beyond talk: Creating autonomous motivation through self-determination theory. Journal of General Management, 34, 75-91. 
Sudrajat, Akhmad. (2010). Profesionalisme Guru. Akhmadsudrajat.wordpress.com /2010/11/07/tentangprofesionalisme-guru/. Akses tanggal 11 April 2015

Usher, E., \& Pajares, F. (2008). Sources of self-efficacy: Critical review of the literature and future directions. Review of Educational Research, 78, 751-796.

Walton, G. M., \& Spencer, S. J. (2009). Latent ability: Grades and test scores systematically underestimate the intellectual ability of negatively stereotyped students. Psychological Science, 20, 1132-1139.

Willis, J. (2010). Learning to love math: Teaching strategies that change student attitudes and get results. Alexandria, VA: Association for Supervision \& Curriculum Development.

Wilson, T. D. (2006). The power of social-psychological interventions. Science, 313(5791), 1251-2.

Yeager, D. S., \& Walton, G. M. (2011). Social-psychological interventions in education: They're not magic. Review of Educational Research, 81(2), 267-301.

Zuchdi, D. dkk. (2013). Model Pendidikan Karakter: Terintegrasi dalam pembelajaran dan Pengembangan Kultur. Yogyakarta: UNY Press.

Zuchdi, Darmiati. (2010). Pendidikan Karakter Dengan Pendekatan Komprehensif, UNY Pres, Yogyakarta. 
